\title{
Sickle cell disease in the tribal population attending tertiary referral centre in Surguja district of Chhattisgarh
}

\author{
Mallik $\mathbf{M}^{1}, \operatorname{Singh} \mathrm{A}^{2}$, Mallick $\mathrm{S}^{3}$ \\ ${ }^{1}$ Dr. Mahasweta Mallik, Department of Pathology, Associate Professor, Government, Medical College, Ambikapur, ${ }^{2}$ Dr. \\ Alka Singh, Department of Pathology, Assistant Professor, Government Medical, College, Ambikapur, ${ }^{3}$ Dr. Sujata \\ Mallick, Department of Pathology, Assistant Professor, KPC Medical College, Jadavpur, Kolkata, West Bengal, India
}

Address for Correspondence: Dr. Mahasweta Mallik, Email id: coolsama6773@yahoo.co.in

\begin{abstract}
Background: sickle cell anaemia is a haemoglobin disorder which is autosomal recessive. As it is inherited disorder it is prevalent more in tribal population of India. Surguja district of Chhattisgarh also has a predominance o of tribal population. Aim: Aim of this study is to find the incidence of sickle cell disease in the tribal population attending the tertiary referral hospital of surguja district. Material and method: This is a retrospective study of a span of $3 y e a r s$ from April 2013 to March 2016. A total of 5489 anaemic patients were tested. Result: out of 5489 anaemic patients 399 were positive for sickle cell. Conclusion: Education and counselling should be done to prevent sickle cell disease among the tribal of surguja district of chattisgarh.
\end{abstract}

Key words: Sickle cell disease, Sickle cell Anaemia (Homozygous), Sickle Cell Trait ( Heterozygyous), Tribal Population

\section{Introduction}

Sickle cell disease is an autosomal disorder [1]. Normal haemoglobin has $\mathrm{HbA}, \mathrm{HbA} 2$ and $\mathrm{HbF}$, while sickle cell disease person has $\mathrm{HbS}$ [2]. In $\mathrm{HbS}$ the biconcave $\mathrm{RBC}$ takes a sickle or boat shape [3]. HbS is produced as a result of replacement of valine by glutamic acid at $6^{\text {th }}$ position in $\beta$ chain $[4,5]$. In 1910 James Herrick, a physician first discovered sickling in a medical student $\mathrm{RBC}$ in Grenada. Sickle cell gene is present worldwide from equator in Africa to sicily, southern Italy, Northern Greece, southern Turkey, Middle East and central India [6]. The gene may be present in homozygous or heterozygous state.

Pathophysiology of sickling is based on the polymerisation of deoxyhaemoglobin $\mathrm{HbS}$ with fibre formation inside RBCs resulting in a distorted sickle shape of RBC which ultimately leads to haemolysis and vaso-occlusion. Clinical presentation is variable. In India, sickle cell haemoglobin was discovered by Lehman and Cutbush in 1952 in the tribal population in

Manuscript received: $06^{\text {th }}$ December 2016

Reviewed: $15^{\text {th }}$ December 2016

Author Corrected: $20^{\text {th }}$ December 2016

Accepted for Publication: $31^{\text {st }}$ December 2016
Nilgiri hills of South India [7]. According to 2011 census of India, out of 67.8 million populations [8], $8.6 \%$ is tribal mainly distributed in Central India in states of Madhya Pradesh, Maharashtra, Odisha, Gujarat, Rajasthan, Jharkhand, Chhattisgarh, Andhra Pradesh and West Bengal.

This study has been undertaken to find out the incidence of sickle cell disease among the tribal population of Surguja district so that pre marriage counselling can prevent the further spread of the disease and prevent morbidity and mortality.

\section{Material and Method}

This study is a retrospective study of a span of 3 years from April 2013 to March 2016. This study was undertaken in a tertiary referral centre of Surguja district of Chhattisgarh. A total of 5489 anaemic patients were tested out of which 922 were male and 4567 were female. Female : male ratio was 4.9:1. This huge ratio gap was present as haemoglobin and sickling are done routinely for all female coming for antenatal examination. 
Inclusion criteria were all patients with haemoglobin less than $9 \mathrm{gm} \%$. All anaemic patients were included in this study. Percentage of patient who were who were positive for sickling were calculated. Out of 5489 anaemic patients attending hospital between year 2013 to 2015 , were examined. 399 were positive for sickling among them.

Sickling was confirmed by solubility test, sodium metabisulfite test and if found positive finally electrophoresis was done.

\section{Result}

Out of 5489 anaemic patients examined over a 3 years period 399 were positive for sickle cell disease.

- 152 patients had sickle cell disease out of 1518 patients in the year April 2013-march 14.

- 128 had sickle cell disease from a total of 2402 patients from April 2014 to March 15.

- 119 had sickle cell disease out of 1569 patients from April 2015 to march 2016.

Out of 399 cases 223 were female and 176 were male. Female : male ratio was 1.3:1. Mean age of female was 19.2 years. And of male was 14.3 years.

Out of the 399 cases sickle cell anaemia was present in 26 cases had sickle cell trait was present in 373 cases. Patients with sickle cell anaemia were all children below 5 years and patients with sickle cell trait were from 0-25 years.

Table-1: April 2013 to march 2016

\begin{tabular}{|c|c|c|c|}
\hline Sr. No & Year & Total sample tested & Positive \\
\hline 1. & April 2013 to March 2014 & 1518 & 152 \\
\hline 2. & April 2014 to March 2015 & 2402 & 128 \\
\hline 3. & April 2015 to March 2016 & 1569 & 119 \\
\hline Total & 3 years & $\mathbf{5 4 8 9}$ & $\mathbf{3 9 9}$ \\
\hline
\end{tabular}

\section{Discussion}

Sickle cell disease is an autosomal recessive inheritable disease. According to Veron Ingram the disease is due to a single base $\mathrm{A}$ to $\mathrm{T}$ mutation in the triplet encoding the $6^{\text {th }}$ residue of the $\beta$ globin chain resulting in the substitution of glutamic acid by valine and forming an abnormal HbS $[9,10]$. Globin is produced in the $\mathrm{p}$ arm of chromosome 11. As sickle cell disease is has an autosomal ressesive inheritance, child inherits haemoglobin gene from both patents. If a person is heterozygous for $\mathrm{HbS}$ ( 1 normal gene and 1 sickle gene), he has sickle cell trait and can produce $50 \%$ normal haemoglobin. If a person is homozygous for $\mathrm{HbS}$ gene all his RBC form sickle. This makes the RBCs fragile resulting in low oxygen carrying capacity. The sickle shaped RBCs have difficulty in passing through narrow vasculature like capillaries resulting in vaso-occlusion.

The sickle RBC in solubility test shows turbidity instead of transparent solution. Sensitivity and specificity of solubility test is $97.4 \%$ and $100 \%$ respectively. So can be conduct this test for its cost effectiveness in remote areas also [11]. In sodium metabisulphite the RBCs become sickle shaped in absence of oxygen instead of normal biconcave shape. Haemoglobin electrophoresis shows an abnormal HbS band. Sickle cell trait shows two bands one normal $\mathrm{HbA}$ band and other abnormal HbS band.

According to Allison hypothesis Sickle cell trait is present in hyperendemic areas of falciparum malaria to prevent malaria [12]. A co-relation between sickle cell trait and malarial endemicity has been found in the tribal population of central India and Maharashtra [13].

In our study sickle cell disease was more in female than in male as more female are screened than male in our hospital. All female who came for antenatal check up are screened for sickle cell. So it is incidental finding. Other studies show more male suffering from sickle cell disease [14]. Due to the high incidence of sickle cell disease in surguja district education and counselling needs to be done. Premarital counselling can prevent sickle cell anaemia if both partners have traits then chances of offspring with sickle cell anaemia is $25 \%$. 
Pre natal diagnosis by amniotic fluid examination on 12-14weeks of pregnancy can also be helpful.

\section{Conclusion}

As we see the presence of sickle cell disease among the tribals is high so screening needs to be done properly. Also awareness programs need be started with the help to educate and counsel. These measures will help in preventing the spread of sickle cell disease.

Funding: Nil, Conflict of interest: None initiated,

Permission from IRB: Yes

\section{Reference}

1. Bush RL, Pevec WC, Holcroft JW. A prospective, randomized trial limiting perioperative red blood cell transfusions in vascular patients. Am J Surg. 1997 Aug;174(2):143-8.

2. Vincent JL, Baron JF, Reinhart K, Gattinoni L, Thijs L, Webb A, Meier-Hellmann A, Nollet G, Peres-Bota D; ABC (Anemia and Blood Transfusion in Critical Care) Investigators. Anemia and blood transfusion in critically ill patients. JAMA. 2002 Sep 25;288(12):1499-507.

3. Masom VR, Sickle cell anaemia, severe anaemia with remarkable elongated shaped red blood cells. J Am Med Assoc 1922 Oct:79:1318-20

4. Claster S, Vichinsky EP. Managing sickle cell disease. BMJ. 2003 Nov 15;327(7424):1151-5.

5. Saunthararajan Y,Vichinsky EP. Sickle cell disease: Clinical features and management. In: Hoffman R, Benz EJ Jr, Silberstein LE. Heslop HE, Weitz JI, editors. Haematology: Basic principles and Practice, $6^{\text {th }}$ edition, Ch.40, Philadelphia, PA: Saunders Elsevier:2012

6. Herrick JB. Peculiar elongated and sickle shaped red blood corpuscles in a case of severe anaemia. Arch
Intern Med 1910: 6:517-21. Cited from Bridges KR. A brief history of sickle cell disease. April 2002. Available from :http://.Innvista.com/health/ailments/anaemias/sickhist.h tm.

7. Lehmann H, Cutbush M. Sickle-cell trait in southern India. Br Med J. 1952 Feb 23;1(4755):404-5.

8. Census of India 2011. Office of the Registrar General and Census Commissioner.Ministry of home Affairs, Govt of India. Available from:http://www.censusindia.gov.in, accessed on March $27,2015$.

9. Stuart MJ, Nagel RL. Sickle-cell disease. Lancet. 2004 Oct 9-15;364(9442):1343-60.

10. Rees DC, Williams TN, Gladwin MT. Sickle-cell disease. Lancet. 2010 Dec 11;376(9757):2018-31. doi: 10.1016/S0140-6736(10)61029-X. Epub 2010 Dec 3.

11. Surve RR,Mukherjee MB, Kate SL, Nagtilak SB, et al. Detection of beta $S$ gene: An evaluation of solubilitytest against automated chromatography and haemoglobin electrophoresis. $\mathrm{Br} \mathrm{J}$ Biomed sci 2000;57(4):292-4

12. Allison AC. Protection afforded by sickle-cell trait against subtertian malareal infection. Br Med J. 1954 Feb 6;1(4857):290-4.

13.Deshmukh VV. Deficiency of erythrocyte glucose-6phosphate dehydrogenase and sickle cell trait, a survey at Aurangabad, Maharashtra. Ind J Med Res 1968;56 (6): $821-825$

14. Urade BP. Sickle cell gene(HbS). Scenario in Tribal India. J health Med Inform, July 2012, 3:114. Doi:10.4172/2157-7420.1000114.

\section{How to cite this article?}

Mallik M, Singh A, Mallick S. Sickle cell disease in the tribal population attending tertiary referral centre in Surguja district of Chhattisgarh. Int J Med Res Rev 2016;4(12):2223-2225.doi:10.17511/ijmrr. 2016.i12.24. 